\title{
POLITICAL STABILITY AND ECONOMIC GROWTH RELATION: THE CASE OF TURKEY AND TURKIC REPUBLICS
}

DOI: 10.17261/Pressacademia.2020.1293

JEFA- V.7-ISS.3-2020(6)-p.263-273

\section{Yavuz Ozek}

Firat University, Vocational College of Social Sciences, Banking and Insurance Department, Elazıg, Turkey. yozek@firat.edu.tr, ORCID: 0000-0003-4517-4875

Ozek, Y., (2020). Political stability and economic growth relation: The case of Turkey and Turkic republics. Journal of Economics, Finance and Accounting (JEFA), V.7(3), p.263-273.

Permanent link to this document: http://doi.org/10.17261/Pressacademia.2020.1293

Copyright: Published by PressAcademia and limited licensed re-use rights only.

\section{ABSTRACT}

Purpose - The purpose of this study is to investigate the possible relation between political stability and economic growth in Turkey and Central Asian Turkic Republics namely, Azerbaijan, Kazakhstan, Kyrgyzstan, Uzbekistan, Tajikistan and Turkmenistan. By doing so, we will be able to conclude the effect of political stability on transition economies such as Turkic countries.

Methodology - We employ panel data analysis methods which take cross section dependency into account. In this regard, we employ cross section dependency test and unit root tests. In the second step, we use panel unit root co-integration test. At the end we employ panel VAR causality and Köse and Emirmahmutoğlu Panel causality tests.

Findings- Results imply that there is a uni-directional causality running from gross domestic product per capita to political stability. In country based analysis, it is seen that the causation linkage running from political stability to economic growth occurs in only Azerbaijan. In other countries, there is no relationship between variables.

Conclusion- According to results, it is possible to conclude that political stability is not a pre-condition of economic growth in Turkic economies, except Azerbaijan. On the other hand, political stability might be a pre-condition of another macroeconomic indicator such as inflation, trade opennes and etc.

Keywords: Central Asia, political stability, economic growth, panel data, causality.

JEL Codes: E00, C23, P48

\section{INTRODUCTION}

Expressing the interaction between politics and economy, political stability is a concept that develops around the new institutional economics approach and is intertwined with both politics and economy. This concept, which has gained increasing importance with the increase of international integration, has attracted the attention of many researchers and the relationship between political stability and economic indicators has become one of the frequently encountered issues in the literature.

Determining the relationship between political stability and macroeconomic indicators is very important for decision makers to guide their policies. In order to establish a stable political structure, there is a need for legitimate governance that is far from arbitrary practices, bound by rules and laws, and highly accountable. In addition, decision makers should not ignore that the political decisions they make and the policies they set would affect the economy. Predictability is very important for investors. The more positive expectations economic actors have about the future, they invest more. The atmosphere of confidence created by a stable political order contributes to the increase of positive expectations about future by eliminating uncertainty. While this situation makes the existing investments permanent, it also serves as an incentive for new investors. Otherwise, the uncertainty caused by an unstable structure will increase the level of risk, negatively affect the economic indicators, and will especially push foreign investors to seek safe havens. In addition, the chaos environment created by political instability will put pressure on government and cause loss of reputation both in domestic politics and in the international political arena. 
The political stability is a very important concept in terms of emerging economies those begun to integrate with international markets. A politically stable structure is both an international reputation and an important reference source for foreign investors.

The aim of this study is to investigate possible relation between political stability and economic growth in Turkey and Central Asian Turkic Republics. While Turkey is an emerging market economy, Central Asian Turkic Republics have entered the process of integration with international markets by switching from the centrally planned system to the market economy. The contribution of the study to existing literature is that although there are numerous studies examining the relation for emerging and developed economies, there are insufficient studies examining transition economies such as Central Asian Turkic countries. To my knowledge, this is one of the initial study investigating Central Asian Turkic economies.

The first section of the study includes theoretical framework on political stability, literature survey and graphs of development of variables investigated. In the second section, analysis method employed and results of empirical analysis are presented. In conclusion section, evolutions are made for the results of empirical analysis.

\section{THEORETICAL BACKGROUND OF POLITICAL STABILITY/INSTABILITY NOTION AND LITERATURE REVIEW}

Political stability is an essential notion to be able to manage process in both private and public sector and it means lack of change and movement. In the case of absence of political stability, it is very possible beginning of uncertainty and loss of welfare. The basic component of political stability is predictability. Presence of opponents is the key of the political stability. Political stability expresses a set of rules which is established at the beginning and ensures the predictability where opponents are institutionally recognized.

Political stability is a notion appeared first in 1960s. Confusion about the explanation of this concept has continued until today. In studies examining the effect of political instability on growth, this state of uncertainty shows its effect. In researches related to political stability notion it is seen that frequent government changes, increase in anti-government demonstrations and actions and coups cause a politically unstable structure (Curvale, 2010: 1-12).

Huritz synthesizes different articles and collates conditions necessary for the existence of political stability in a system as follows:

- $\quad$ Persistence: The ability of the political system to continue

- Legitimacy: The existence of a legitimate political system

- Effectiveness: The ability to make effective decisions by the political system

For a politically stable structure, "persistence", that is, the absence of frequent government changes, is an important condition. Since there is an uncertainty about the descriptive use of these three conditions that Huritz envisages, it is discussed in the literature that in order to build stronger political stability, "legitimacy" and "efficiency" for "persistence" or "persistence" for "legitimacy" and "effectiveness"? (Park, 1982: 12).

Interaction between political decisions and economic indicators constitutes main subject of political economics and constitutes policymakers' performances on solution of economic problems. In other words, the most important results of political decisions are seen on the field of economics. In this regard, political stability defined as stability in political decisions and political order is effective on economic order, development and stability (Çalışkan, 2019: 72).

In order to build politically stable environment, institutional factors are too undeniable. Also, it is a view in the economic literature that the increase in institutional quality positively affects economic performance. Institutions have an impact on the economic performance of the countries by reducing the uncertainty and affecting transaction costs, directing economic activities to productive areas, and enhancing cooperation and trust (Gökalp and Baldemir, 2006: 212).

Democratic framework and institutional stability are crucial for political stability. Lack of them in a system can ruin the best policies and growth initiatives. Increasing uncertainty about the future and increasing the level of risk may cause political instability and cause the funds of domestic and foreign capital owners to shift to new investment projects. In addition, regime and frequent government changes make rational expectations impossible.

In an unstable environment, investors will seek a more stable environment for reasons such as credit default risk, weakening the principle of private property and less trust in the judiciary, and will choose to shift their investments to foreign countries. Decreasing investments because of outflowing investments due to unstable structure induces economic problems such as decreasing labor demand and increasing unemployment. The persistence of instability will further undermine the political structure, leading to the skilled labor migration required for efficient production. Thus, less capital and labor will reduce total 
production and lower labor quality will slow down economic growth by affecting productivity negatively (Comeau, 1998: 5557).

In the economic literature, there are numerous many studies examining the effects of political stability / instability on countries' economic performance. The uncertainty created by instability in an economy confronts as an undesirable situation for policy makers and economic actors. When the related literature is reviewed, it is possible to conclude that a politically stable structure has a positive effect on macroeconomic indicators, political instability affects these indicators negatively. Negative effect will increase when instability increases.

Asghar et al. (2015) analyzes relation between institutional quality and economic growth in thirteen Asian economies. In the study authors employ panel data method to examine period between years 1990 and 2013. According to findings, there is a uni-directional causality running from institutional quality to economic growth and institutional quality affects economic growth positively.

Sekrafi and Sghaier (2018) investigate effects of energy consumption, corruption, quality of environment and political stability on economic growth in thirteen Middle Eastern and North African (MENA) countries. The study analyzes $1984-2012$ period via static and dynamic panel data methods. According to analysis results, increasing corruption is effective on economic growth, environmental quality and energy consumption directly. Also economic growth affects environmental deterioration and political instability negatively.

Çetin (2019 investigates the effect of economic and political institutions on economic growth in twenty six countries. The data belonging to variables cover $2002-2016$ period. The author analyzes the countries into two groups namely, developed and emerging market economies. According to analysis results obtained from generalized OLS (FGLS, hereafter), there is positive and statistically significant relation between economic growth and indicators those are employed to build World Governance Index that is substituted to measure economic and political institutions.

Çalışkan (2019) examines the relation between political stability and financial development in the Turkish economy. In the study, Çalışan employs Granger causality test to analyze 1970 - 2017 period. According to empirical analysis results, there is a long run relation between financial development and political stability and also causation linkage between political stability and financial development.

Karakuzu and Limon (2019) analyze the Tunusian economy in the context of effect of political stability on political and social life. The authors employed human development index, Failed / Fragile State Index, Global Peace and Terror Indices. They analyze 2010 - 2018 period. According to results obtained, unless governments answer needs of democracy, they would face with riots and revolts. Also, economic crises and inequality in income distribution trigger political instability.

Demez et al. (2019) investigate relation between economic growth and political stability in NIC countries. Authors employ bootstrap panel causality test developed by Konya (2006) in order to find possible causation linkage between variables between years 2002 and 2017. As a result, there is a uni-directional causality running from economic growth to political stability in only Indonesia and Turkey.

Kamacı (2019) investigates the relation for twenty OECD countries in between 2003 - 2017 years. Panel data analysis method results show that a $1 \%$ percent increase in political instability decreases real GDP $1,784 \%$ in the long run, while it increases economic growth $5,244 \%$ in the short run.

YIImaz (2019) analyzes the interaction between political instability and economic indicators for nine countries between years 2010 and 2017 via panel data analysis method. According to results obtained, there is no relation between economic growth and political instability. On the other hand, results imply a negative weak correlation between political instability and foreign direct investment inflow and outflow, inflation rate and exchange rate.

In Graph 1, it can be seen that development of political stability level of selected economies during years between 2002 and 2018. There is no considerable volatility in Azerbaijan, Kyrgyzstan and Tajikistan during the years and level of stability is close to each other. When other economies in the graph investigated, it is possible to say that level of political stability index decreased between years 2002 and 2005 in Uzbekistan. After this period, it has been started to increase in 2005 till 2018. Break point of political stability level of Uzbekistan is year of 2005. When we look closer, it is possible to conclude that there are some important changes in economic management. In this period, Uzbekistan was in a situation such as closed economy. In 2005, "Foreign Investments Law" which was accepted in 1998, was changed and by the change, foreign direct investment inflow into country is stimulated and foreign investors are privileged via tax and customs duty exemptions. 
Graph 1: Political Stability Index During 2002 - 2018 Years

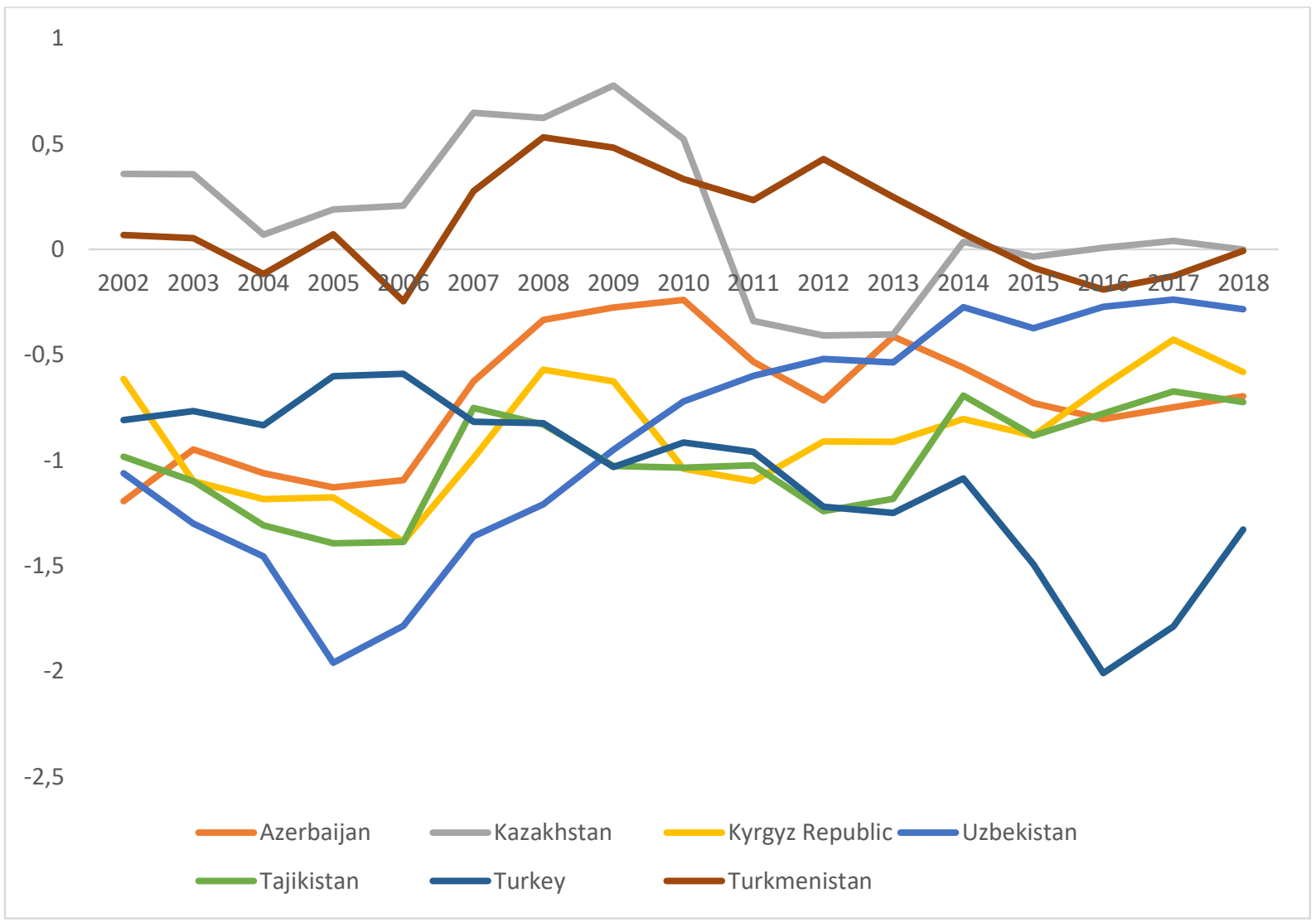

Source: World Bank, 2019.

The trend between years 2007 and 2015 is positive in Turkmenistan and the lowest level was seen in 2006. After the death of former Turkmenistan head of state Niyazov, Berdimuhammedov was selected of new head of state in 2007. Contrariwise of Niyazov's closed economy policy, Berdimuhammedov has given international relations and implemented policies in order to increase foreign trade capacity, especially for energy sources that the country has. It is seen that the policies pursued to develop the relations and to open out also reflected to the level of political stability.

Kazakhstan is the country with the highest level of political stability among the analyzed economies. On the other hand, the level of political stability in Kazakhstan showed a downward trend between 2009 and 2013, while the average course continued in other years. Kazakhstan suspended membership negotiations with the World Trade Organization, which has been going on for many years in 2009, and was included in the Customs Union Agreement between Russia and Belarus as of 2010. However, Kazakhstan could not achieve the desired result from this agreement. According to analysis for 2010-2015 period, made by Barak and Abutalipov (2016), the Customs Union Agreement between Kazakhstan, Russia and Belarus does not have any positive effect on foreign trade volume of Kazakhstan. The country officially became a member of World Trade Organization in 2015.

In Turkey, political stability index has an average cruise during whole period, but trend of index presents a negative trend between years 2014 and 2016. It is possible to conclude that coup attempt occurred in 15th of July 2016 was effective on the negative trend which is is accepted as a major indicator of political instability. But the Turkish economy was not influenced in a long time period and entered into a rapid recovery period. Recovery process also influenced the level of political stability. As of the end of 2016, it gained momentum and increased. 
Graphic 2: Development of GDP Per Capita in 2002 - 2018 Period

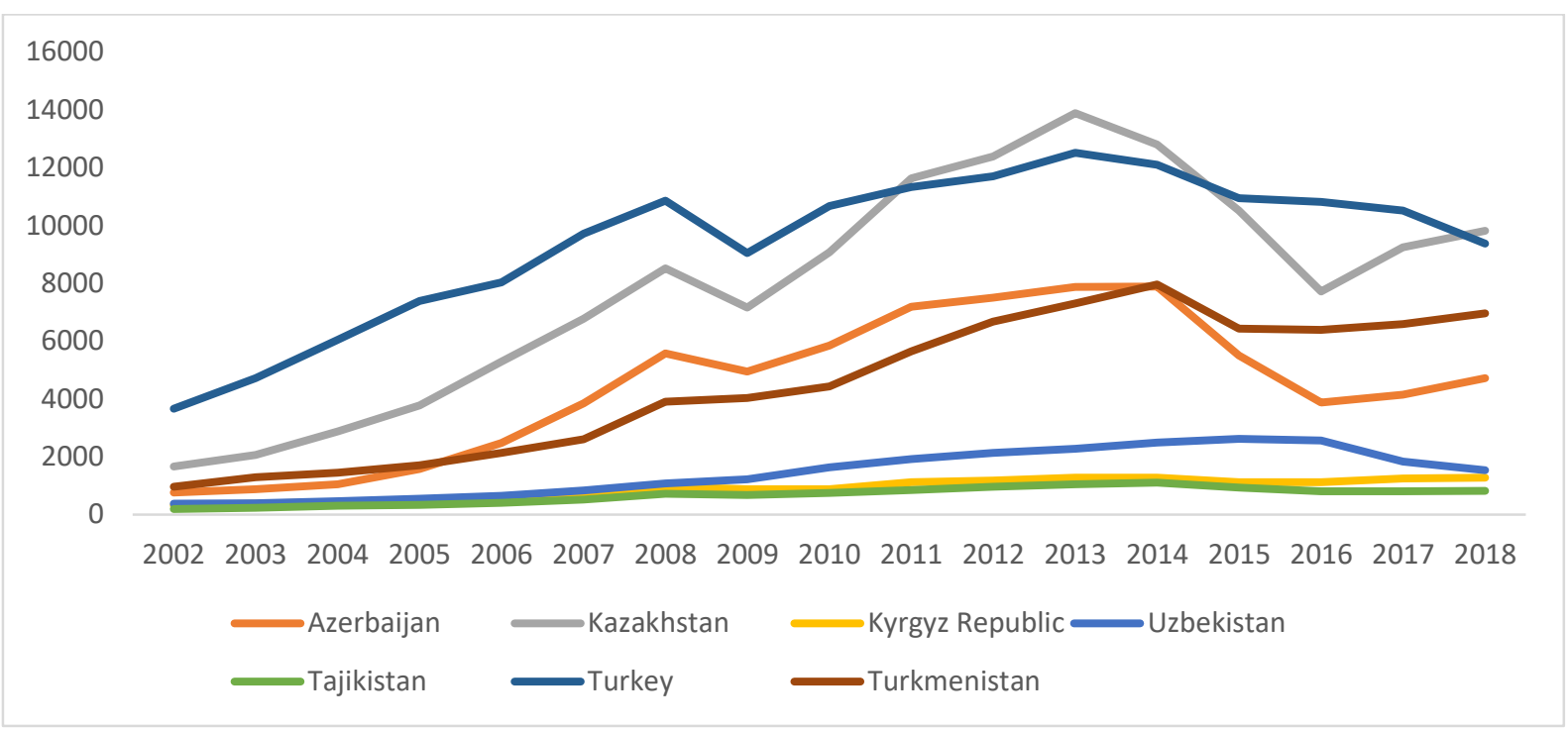

Source: World Bank, 2019.

In Graph 2, change in gross domestic per capita of each countries examined are presented for $2002-2018$ period. It is interesting that the lowest political stability value belongs to Turkey as indicated in graph 1, the highest gross domestic product per capita value belongs to Turkey too. Among Central Asian Turkic countries, Kazakhstan, which is the most developed economy, stands out with its high gross domestic product per capita. The economic development of Turkmenistan, Azerbaijan and Uzbekistan economies have followed similar pathways. Gross domestic product per capita of Kyrgyzstan and Tajikistan have increased in the same ratio.

\section{EMPIRICAL FINDINGS}

In this study, relation between political stability and economic growth is investigated in Azerbaijan, Kazakhstan, Kyrgyzstan, Uzbekistan, Tajikistan, Turkish and Turkmenistan economies. Annual data belonging to $2002-2018$ period is employed. Political stability (PS, hereafter) and gross domestic product per capita (GDPPC, hereafter) are used as variables denoting political stability and economic growth, respectively. Data belonging to variables PS and GDPPC are obtained from World Bank database. Cross section dependency, unit root and causality tests are employed. In order to test cross section dependency test, Lagrange Multiplier test developed by Breusch and Pagan (1980) are used. Panel data model where size of cross section is $\mathrm{i}=1,2, \ldots, \mathrm{N}$, time size is $\mathrm{t}=1,2, \ldots, \mathrm{T}, \alpha_{i}$ and $\beta_{i}$ are constant term and slope coefficients, respectively, $x_{i t}$ is descriptive variables vector and its size is $k \times 1$;

$y_{i t}=\alpha_{i}+\beta_{i}^{\prime} x_{i t}+\varepsilon_{i t}$

In the model, LM test statistic is $\left[H_{0}: \operatorname{Cov}\left(\varepsilon_{i t}, \varepsilon_{j t}\right)=0\right.$ ];

$L M=T \sum_{i=1}^{N-1} \sum_{j=i+1}^{N} \hat{\rho}_{i j}^{2} \sqcap \chi_{N(N-1) / 2}^{2}$

\footnotetext{
${ }^{1}$ World Bank definations of political stability: “Political Stability and Absence of Violence/Terrorism measures perceptions of the likelihood of political instability and/or politically-motivated violence, including terrorism. Estimate gives the country's score on the aggregate indicator, in units of a standard normal distribution, i.e. ranging from approximately - 2.5 to 2.5 " (World Bank Database, 2020)
} 
$\hat{\rho}_{i j}^{2}$ denotes sectional correlation obtained from individually employed ordinary least squares method. Pesaran (2004) finds a new LM test statistics in order to prevent size distortion. LM statistics which is modified as time size is T $\rightarrow \infty$ and sectional size is $\mathrm{N} \rightarrow \infty$ is as follows; ${ }^{2}$

$C D=\sqrt{\left(\frac{2 T}{N(N-1)}\right)}\left(\sum_{i=1}^{N-1} \sum_{j=i+1}^{N} \hat{\rho}_{i j}\right) \square N(0,1)$

If there is no cross sectional dependency, first generation unit root tests are employed. If there is a cross sectional dependency, second generation unit root tests are employed. In order to test validity of cross section dependency in the panel data analysis, $C D_{\llcorner M}$ test developed by Pesaran (2004), $C D_{\llcorner M 1}$ test developed by Breusch - Pagan (1980) and $C D_{L M 2}$ test developed by Pesaran (2007) are employed. If time size is bigger than cross sectional size ( $T>N), C D_{\llcorner M 1}$ and $C D_{\llcorner M 2}$ tests are employed. If cross sectional size is bigger than time size $(N>T), C D_{L M}$ test is employed.

The null hypothesis in cross sectional dependency tests is "there is no cross section dependency and alternative hypothesis denotes validity of cross section dependency.

Table 1: Cross Section Dependency Tests Results

\begin{tabular}{ccc}
\hline Model with Constant & PS & GDPPC \\
\hline$C D_{l m}$ & $28.552(0.125)$ & $33.54(0.041)^{* *}$ \\
$C D_{l m}$ & $1.165(0.122)$ & $1.935(0.026)^{* *}$ \\
$C D$ & $-2.655(0.00)^{* * *}$ & $-1.519(0.064)^{*}$ \\
$L M_{a d j}$ & $3.766(0.00)^{* * *}$ & $-0.907(0.818)$ \\
\hline
\end{tabular}

Notes: In the following model $\Delta y_{i, t}=d_{i}+\delta_{i} y_{i, t-1}+\sum_{j=1}^{p_{i}} \lambda_{i, j} \Delta y_{i, t-j}+u_{i, t}$, lag length $\left(\mathrm{p}_{\mathrm{i}}\right)$ is acceptes as $1 .{ }^{* * *}, * *$ and $*$ denote that alternative hypothesis is accepted in $1 \%, 5 \%$ and $10 \%$ significance levels, respectively.

According to probability values, alternative hypothesis which claims validity of cross section dependency is accepted. Second generation unit root tests are capable to test whether variables are stationary for each country and it is valid in the case of T>N. Seemingly Unrelated Regression Augmented Dickey Fuller test (SURADF, hereafter) developed by Breuer et al. (2002) is panel data analysis version of conventional generalized Dickey - Fuller unit root test for time series. In SURADF test is calculated as follows where $\mathrm{N}$ denotes the number of countries;

$$
\begin{aligned}
& \Delta y_{1 t}=\alpha_{1}+\beta_{1} y_{1 t-1}+\delta_{1 t}+\sum_{j=1}^{p 1} \varphi_{1 j} \Delta y_{1 t-j}+\varepsilon_{1 t} \\
& \Delta y_{2 t}=\alpha_{2}+\beta_{2} y_{2 t-1}+\delta_{2 t}+\sum_{j=1}^{p 1} \varphi_{2 j} \Delta y_{2 t-j}+\varepsilon_{2 t} \\
& \Delta y_{N t}=\alpha_{N}+\beta_{N} y_{N t-1}+\delta_{N t}+\sum_{j=1}^{p 1} \varphi_{N j} \Delta y_{N t-j}+\varepsilon_{N t}
\end{aligned}
$$

In this case, $\mathrm{N}$ null and alternative hypotheses are established for each country in the panel. In SURADF test, the null hypothesis claims the existence of unit root in the serie and alternative hypothesis claims that there is no unit root in the related serie. If the test statistic of SURADF is smaller than critical value, it is possible to imply that variable belonging to related country is stationary. If the test statistics of SURADF is bigger than critical value, it means that null hypothesis claiming the existence of unit root is accepted.

${ }^{2}$ Since pair-wise correlations are not distributed with zero mean, Pesaran et al. (2008) can be examined for bias-adjusted LM test statistics for large panels. 
Table 2: SURADF Unit Root Test Results

\begin{tabular}{|c|c|c|c|c|c|c|}
\hline & \multicolumn{3}{|c|}{$\begin{array}{c}\text { Model with Constant } \\
\text { Term } \\
\end{array}$} & \multicolumn{3}{|c|}{ Model with Constant Term and Trend } \\
\hline & Lags & SURADF t-stat & $10 \%$ & Lags & SURADF t-stat & $10 \%$ \\
\hline \multicolumn{7}{|l|}{ PS } \\
\hline Azerbaijan & 1 & -6.5419 & -3.4765 & 3 & -6.1779 & -6.0180 \\
\hline Kazakhstan & 1 & $-2.3140 *$ & -4.3891 & 4 & -4.8419 & 1.6461 \\
\hline Kyrgyzstan & 4 & $-3.6838^{*}$ & -5.0770 & 3 & $-4.4984 *$ & -5.3820 \\
\hline Uzbekistan & 4 & -9.9730 & -6.0475 & 4 & $-1.7847^{*}$ & -6.1989 \\
\hline Tajikistan & 4 & $-2.8973 *$ & -5.3498 & 2 & $-3.8697^{*}$ & -5.1964 \\
\hline Turkey & 1 & $-3.4473 *$ & -4.2565 & 1 & $-7.2618^{*}$ & -7.3078 \\
\hline Turkmenistan & 4 & -4.1293 & 0.3758 & 4 & $-5.5450 *$ & -8.4657 \\
\hline \multicolumn{7}{|l|}{ GDPPC } \\
\hline Azerbaijan & 1 & -6.4393 & -4.9484 & 2 & $-4.3726 *$ & -6.7894 \\
\hline Kazakhstan & 1 & $-3.5484^{*}$ & -4.0959 & 1 & $-3.7053^{*}$ & -7.7408 \\
\hline Kyrgyzstan & 2 & $-4.7373^{*}$ & -5.1622 & 1 & $-5.6562 *$ & -8.9847 \\
\hline Uzbekistan & 4 & 0.3612 & -5.5938 & 4 & -4.9348 & -0.1073 \\
\hline Tajikistan & 2 & -5.0235 & -4.4443 & 2 & $-4.7418^{*}$ & -6.2939 \\
\hline Turkey & 1 & $-3.7164^{*}$ & -5.0767 & 1 & $-2.5691^{*}$ & -8.5840 \\
\hline Turkmenistan & 2 & $-3.5044^{*}$ & -5.7954 & 2 & $-4.7120 *$ & -5.3168 \\
\hline
\end{tabular}

Notes: Maximum lag length is determined as four and optimal lag length are determined according to Schwarz information criterion. Critical values are obtained from 1.000 bootstrap simulation. ${ }^{* *},{ }^{* *}$ and ${ }^{*}$ denote acceptance of alternative hypothesis in significance levels $1 \%, 5$ $\%$ and $10 \%$, respectively.

According to SURADF unit root test results presented in table 2, series of Kazakhstan, Tajikistan, Kyrgyzstan and Turkey belonging to political stability index are stationary in model with constant and series of Kyrgyzstan, Uzbekistan, Tajikistan, Turkey and Turkmenistan belonging to political stability are stationary in model with constant and trend. Test results also imply that in Kazakhstan, Kyrgyzstan and Turkey, GDPPC series are stationary in model with constant and in all countries except Uzbekistan; GDPPC series are stationary in model with constant and trend. But it is assumed that both series have long run memory features and first difference of series will be employed in empirical analyzes.

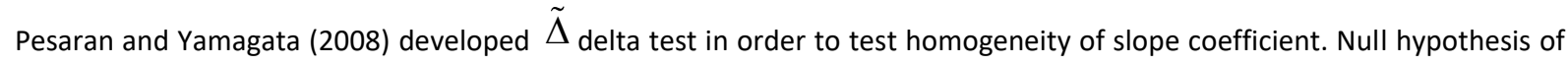
test is homogeneity of slope coefficient [ $H_{0}: \beta_{i}=\beta_{\text {] for each }{ }^{3} \text {. }}$

Table 3: Cross Section Dependency and Homogeneity Tests Results

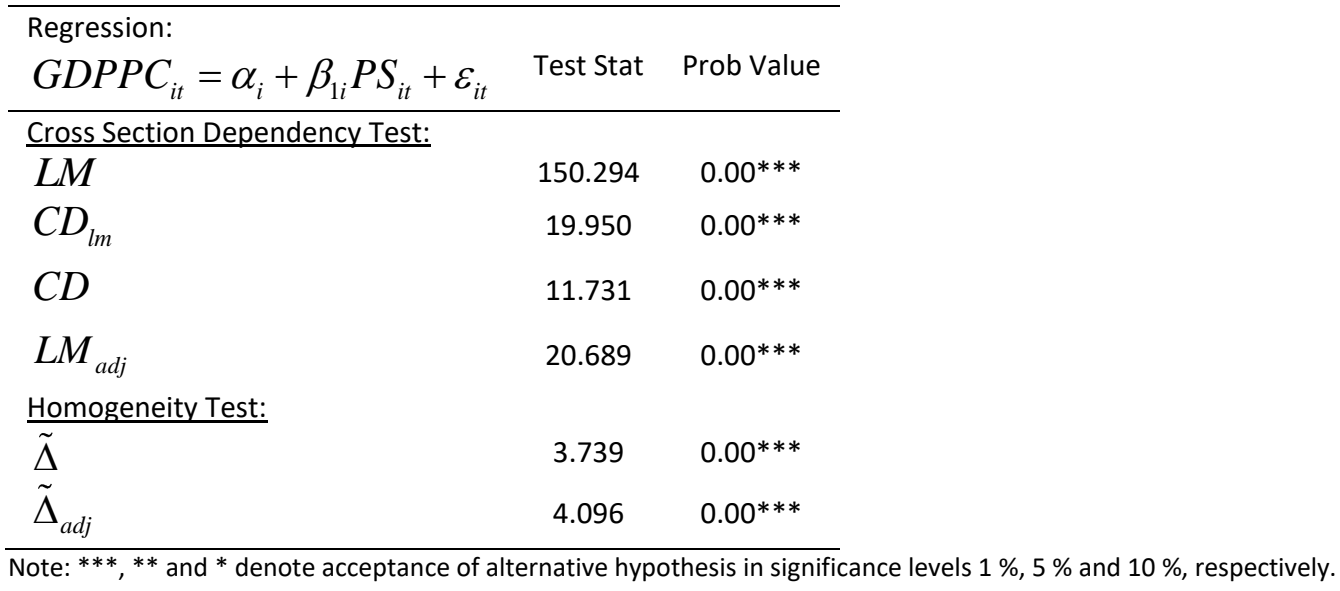

${ }^{3}$ For test stats, please see Pesaran and Yamagata (2008). 
Results imply that co-integration methods based on heterogonous estimation and taking cross section dependency into account have to be employed.

Table 4: Results of No Structural Break Co-integration Tests Taking Cross Section Dependency

\begin{tabular}{|c|c|c|c|c|c|c|}
\hline & \multicolumn{3}{|c|}{ Model with Constant Term } & \multicolumn{3}{|c|}{ Model with Constant Term and Trend } \\
\hline & $\begin{array}{l}\text { Test } \\
\text { Stat }\end{array}$ & $\begin{array}{l}\text { Asymptotic } \\
\text { Prob Value }\end{array}$ & $\begin{array}{l}\text { Bootstrap } \\
\text { Prob Value }\end{array}$ & $\begin{array}{l}\text { Test } \\
\text { Stat }\end{array}$ & $\begin{array}{l}\text { Asymptotic } \\
\text { Prob Value }\end{array}$ & $\begin{array}{c}\text { Bootstrap } \\
\text { Prob Value }\end{array}$ \\
\hline \multicolumn{7}{|c|}{ Error Correction Model } \\
\hline Group_tau & -0.091 & 0.464 & 0.636 & -0.543 & 0.294 & 0.578 \\
\hline Group_alpha & -0.593 & 0.723 & 0.667 & -1.546 & 0.061 & 0.326 \\
\hline Panel_tau & -1.101 & 0.136 & 0.490 & -0.625 & 0.266 & 0.336 \\
\hline Panel_alfa & -0.307 & 0.379 & 0.626 & -2.156 & 0.016 & 0.300 \\
\hline
\end{tabular}

Notes: Null hypothesis of test claims that there is no co-integration. In error correction test, lag and antecedent are accepted as one. Bootstrap probability value are obtained from 1.000 bootstrap simulation. Asymptotic prob values are obtained from standard normal distribution. ${ }^{* * *}, * *$ and $*$ denote acceptance of alternative hypothesis in significance levels $1 \%, 5 \%$ and $10 \%$, respectively.

In error correction test, when both asymptotic and bootstrap probability values are taken into account, it is possible to conclude that there is no relationship between political stability and gross domestic product per capita in the long run. Panel vector auto-correlation models (PVAR, hereafter) are as follows;

$$
\begin{aligned}
& \triangle G D P P C=\delta_{1 i}+\sum_{p=1}^{k} \delta_{11 i p} \Delta G D P P C_{i t-p}+\sum_{p=1}^{k} \delta_{12 i p} \Delta P S_{i t-p}+v_{1 i t} \\
& \Delta P S=\delta_{2 i}+\sum_{p=1}^{k} \delta_{21 i p} \Delta P S_{i t-p}+\sum_{p=1}^{k} \delta_{22 i p} \Delta G D P P C_{i t-p}+v_{2 i t}
\end{aligned}
$$

In equation seven where first panel VAR model presented, null hypothesis is $\sum_{p=1}^{k} \delta_{12 i p} \Delta P S_{i t-p}=0$ and it claims that there is no causation linkage running from political stability to gross domestic product per capita. Alternative hypothesis is $\sum_{p=1}^{k} \delta_{12 i p} \Delta P S_{i t-p} \neq 0$ and claims there is a uni-directional causality running from political stability to gross domestic product per capita.

In equation eight where second panel VAR model presented, null hypothesis is $\sum_{p=1}^{k} \delta_{22 i p} \Delta G D P P C_{i t-p}=0$ and it claims that there is no causation linkage running from gross domestic product per capita to political stability. Alternative hypothesis is $\sum_{p=1}^{k} \delta_{22 i p} \Delta G D P P C_{i t-p} \neq 0$ and claims there is a uni-directional causality running from gross domestic product per capita to political stability.

Table 5: Panel VAR Causality Test Results

\begin{tabular}{lcc}
\hline & $\Delta$ (PS) & $\Delta$ (GDPPC) \\
\hline$\Delta$ (PS) & - & $0.512(0.474)$ \\
$\Delta$ (GDPPC) & $3.157(0.076)^{*}$ & - \\
\hline
\end{tabular}

Note: ${ }^{* *},{ }^{* *}$ and ${ }^{*}$ denote acceptance of alternative hypothesis in significance levels $1 \%, 5 \%$ and $10 \%$, respectively.

According to table 5, there is a uni-directional causality running from GDPPC to PS. But there is no Granger causality running from PS to GDPPC. This result shows that political stability is not a pre-condition of economic growth. So, even if there is an unstable political environment, economic growth can continue. Central Asian Turkic economies are typical transition economies even they are independent since 1990s and transition in democracy may still continue. That is why political 
instability do not affect decisions of households and firms. On the other hand, when governments are successful in economic management, confidence of households and firms to government would increase and that would increase continuity of government. That is one of the measurements of political stability. As a result political stability would increase.

Emirmahmutoğlu and Köse (2011) employ causality test for each cross section by implementing bootstrap method to Fisher test statistics. Before causality test, stationary level $\left(\mathrm{dmax}_{\mathrm{i}}\right)$ and optimal lag length $\left(\mathrm{p}_{\mathrm{j}}\right)$ in panel VAR model are determined by employing unit root test. Then, both coefficients are collected. For each cross section, error correction terms are obtained for regressions below;

$$
\begin{aligned}
& G D P P C_{i, t}=\alpha_{i, t}+\sum_{j=1}^{p_{i}+d \max _{i}} \beta_{i j} G D P P C_{i, t-j}+\sum_{j=1}^{p_{i}+d \max _{i}} \gamma_{i j} P S_{i, t-j}+\varepsilon_{i t} \\
& P S_{i, t}=\alpha_{i, t}+\sum_{j=1}^{p_{i}+d \max _{i}} \beta_{i j} P S_{i, t-j}+\sum_{j=1}^{p_{i}+d \max _{i}} \gamma_{i j} G D P P C_{i, t-j}+\varepsilon_{i t}
\end{aligned}
$$

Null hypothesis of Emirmahmutoğlu and Köse (2011) causality test is $\left[H_{0}: \beta_{i 1}=\beta_{i 2}=\ldots=\beta_{i k_{i}}=0\right.$ ]. Alternative hypothesis claims there is no Granger causality and as follows $\left[H_{0}: \beta_{i 1}=\beta_{i 2}=\ldots=\beta_{i k_{i}} \neq 0\right]{ }^{4}$

Table 6: Emirmahmutoğlu and Köse Panel Causality Test Results

\begin{tabular}{lccccc}
\hline & Lag & \multicolumn{2}{c}{ PS $\neq$ GDPPC } & \multicolumn{2}{c}{ GDPPC $\neq>$ PS } \\
& & Wald & Prob Value & Wald & Prob Value \\
\hline Azerbaijan & 3 & 27.285 & $0.00^{* * *}$ & 2.735 & 0.434 \\
Kazakhstan & 3 & 4.764 & 0.189 & 2.010 & 0.570 \\
Kyrgyzstan & 1 & 0.538 & 0.463 & 0.277 & 0.598 \\
Uzbekistan & 2 & 1.951 & 0.376 & 2.059 & 0.357 \\
Tajikistan & 1 & 0.125 & 0.723 & 0.978 & 0.322 \\
Turkey & 3 & 4.150 & 0.245 & 1.528 & 0.675 \\
Turkmenistan & 1 & 1.058 & 0.303 & 1.250 & 0.263 \\
\hline \multicolumn{1}{c}{ Fisher } & & $\mathbf{3 7 . 0 1 3}$ & $\mathbf{0 . 0 0 * * *}$ & $\mathbf{1 1 . 5 9 4}$ & $\mathbf{0 . 6 3 8}$ \\
\hline
\end{tabular}

Note: $* * *, * *$ and $*$ denote acceptance of alternative hypothesis in significance levels $1 \%, 5 \%$ and $10 \%$, respectively.

According to Emirmahmutoğlu and Köse (2011) causality test results, in only Azerbaijan, there is uni-directional causality running from political stability to gross domestic product per capita in significance level $1 \%$.

The result obtained from Emirmahmutoğlu and Köse (2011) test is important to conclude. Because the members of the CIS (Commonwealth of Independent States), who switched from the central planned system to the market economy, tried to rebuild their countries politically and economically and aimed to be accepted in the international arena. Among them, Azerbaijan has some extra features than others.

According to Dikkaya and Demirci (2013), Heydar Aliyev, who served as the head of state in 1993-2003, has a great contribution in the economic and political shaping of Azerbaijan. The basis of the balance strategy of the country's foreign policy was shaped in this period, which also contributed to the shaping of the economy. While in the beginning of 2000s, the political stability provided by Heydar Aliyev was built on an energy-centered political line, bringing along economic stability. Ilham Aliyev, who was elected president in 2003 after the death of Heydar Aliyev, continued the policies of Haydar Aliyev during his rule and managed to achieve a stable performance in economic growth.

\section{CONCLUSION}

The interaction between political and economic policies is reflected on the political and economic stability levels of the countries and has an impact on their economic indicators. Especially in developing countries, foreign investors have an important role in ensuring sustainable economic stability. Political stability is needed to ensure sustainable economic stability. A politically unstable structure negatively affects economic performance, resulting in uncertainty in the economy. Persistence

\footnotetext{
${ }^{4}$ Please see Emirmahmutoğlu and Köse (2011) for bootstrap test statistics.
} 
of uncertainty causes foreign investors to be annoyed, resulting in a capital outflow from the country. Unlike these negativities, which may be caused by political instability, political stability is essential for governments, because it reduces risk via eliminates uncertainty, improves economic performance and makes investments permanent. Studies that examine the effects of political stability / instability concepts, which are very difficult to measure, on the macroeconomic indicators of countries, have recently come across widely in the literature of economics. In this study, relation between political stability and economic growth in Turkey, Azerbaijan, Kazakhstan, Uzbekistan, Kyrgyzstan, Tajikistan and Turkmenistan is examined for period between years 2002 and 2018. The cross section dependence, panel unit root and panel causality tests are made and annual data belonging to related period is used. In the panel where there is a cross-section dependency, both variables contain unit root in level. According to the panel vector auto-regression model, there is a Granger causality at a $10 \%$ significance level from gross domestic product per capita to political stability. However, there is no causality running from political stability to gross domestic product per capita. According to Emirmahmutoğlu and Köse (2011) causality test results, there is a causation linkage running from political stability to gross domestic product per capita only in Azerbaijan. Determining the relationship between political stability and economic indicators will be a decisive factor in policy makers' political and economic decisions. In this study, the relationship between political stability and economic growth is examined. Political stability is likely to have an impact on other macroeconomic indicators, such as trade openness, exchange rate, inflation and unemployment rates. Examining the relationship between political stability and other macroeconomic indicators for different countries or country groups in future studies will contribute to the literature.

\section{REFERENCES}

Asghar, N., Qureshi, S., \& Nadeem, M. (2015). Institutional Quality and Economic Growth: Panel ARDL Analysis for Selected Developing Economies of Asia. South Asian Studies, 30(2), 381

Barak, O., \& Abutalipov, M. (2016). Kazakistan Rusya Belarus Gümrük Birliği Anlaşmasının Kazakistan'ın Dış Ticareti Üzerine Etkisi. Uluslararası Afro-Avrasya Araştırmaları Dergisi, 1(2), 1-18.

Breuer, B., McNown, R., Wallace, M. (2002). Seriesspecific unit root test with panel data. Oxford Bulletin of Economics and Statistics, 64, $527-46$.

Breusch, T., Pagan, A., (1980). The Lagrange multiplier test and its application to model specification in econometrics. Rev. Econ. Stud. 47, 239-253.

Comeau, L. (1998). Regıme Type, Politıcal Stability, and Economıc Growth. Doctoral Dissertation, University of Illinois at Chicago.

Curvale, A.C. (2010). Does Political Participation A_ect Political Stability? A Study of Latin America During the Nineteenth and Twentieth Centuries. Doctoral Dissertation, New York University.

Çalışkan, Z. D. (2019). Political Stability and Financial Development: Evidence from Turkey. Fiscaoeconomia, 3(3), 72-79.

Çetin, A. B. (2019). iktisadi ve Politik Kurumların Ekonomik Büyüme Üzerindeki Etkisi: Gelişmiş Ülkeler ve Yükselen Piyasa Ekonomileri Karşılaştırması. Bulletin of Economic Theory and Analysis, 4(2), 1-31.

Dikkaya, M., \& Demirci, O. (2013). Petrol Doğal Gaz ve Ötesi: Modern Azerbaycan’da Illham Aliyev Döneminin Ekonomi Politiği. Çağrı Erhan (Edt.). Kafkasya'nın Yükselen Yıldııı Ilham Aliyev Döneminde Azerbaycan, 201-225.

Emirmahmutoğlu, F. And Kose, N. (2011), "Testing for Granger Causality in Heterogeneous Mixed Panels", Economic Modelling , 28, 870876.

Gökalp, M. F., \& Baldemir, E. (2006). Kurumsal yapı ve ekonomik büyüme ilişkisi. Dokuz Eylül Üniversitesi Sosyal Bilimler Enstitüsü Dergisi, $8(1), 212-226$.

Kamacı, A. (2019). Politik İstikrarsızlık-Ekonomik Büyüme iliş̧kisi: 20 OECD Ülkesi İçin Panel Veri Analizi. Başkent Üniversitesi Ticari Bilimler Fakültesi Dergisi, 3(2), 75-85.

Karakuzu, T., \& Limon, İ. (2019). Politik İstikrarsızlık ve Tunus. Electronic Journal of Political Science Studies (EJPSS), 10(2).

Park, H.K. (1982). Polıtıcal Development And Polıtıcal Stabılıty East and Southeast Asıa. Doctoral Dissertation, Cincinnati University.

Pesaran, Hasem, M., (2004), "General Diagnostic Tests for Cross Section Dependence in Panels", Working Paper No:0435, University of Cambridge.

Pesaran, M. H. (2007). A simple panel unit root test in the presence of cross-section dependence. Journal of Applied Econometrics, 22(2), 265-312.

Pesaran, M. H., \& Yamagata, T. (2008). Testing slope homogeneity in large panels. Journal of Econometrics, $142(1), 50-93$.

Pesaran, M.H., Ullah, A., Yamagata, T., (2008). A bias-adjusted LM test of error cross section independence. Econometrics Journal 11, 105127. 
Sekrafi, H., \& Sghaier, A. (2018). Examining the relationship between corruption, economic growth, environmental degradation, and energy consumption: a panel analysis in MENA region. Journal of the Knowledge Economy, 9(3), 963-979.

Turan, I., Demez, S., \& Kızılkaya, F. (2019). NIC Ülkelerinde Politik İstikrar ve Ekonomik Büyüme iliş̧kisi. Siirt Üniversitesi Sosyal Bilimler Enstitüsü Dergisi, 7(14), 485-499.

Yılmaz, A. (2019). Politik İstikrar Endeksi - Ekonomik Göstergeler Arasındaki Etkileşim: Türkiye ve Seçilmiş Ülkeler İ̧̧in Bir Araştırma. Marmara Üniversitesi Sosyal Bilimler Enstitüsü, Yayınlanmamış Yüksek Lisans Tezi, İstanbul. 